\title{
An event-related potential study on the aesthetics of colour matching on silk fabric
}

DOI: $10.35530 / I T .072 .04 .1801$

KAIWEI NIE

RUN WEN

XIAOXIA ZHANG

HUANPING MO

ZHONG WANG

GUOHE WANG

\begin{abstract}
REZUMAT
An event-related potential study on the aesthetics of colour matching on silk fabric

In this work, cognitive behaviour and electroencephalography (EEG) of 16 subjects applied colour matching and contrast colour matching to silk fabrics had been measured. The results showed that, the exogenous components P1 (100 ms) and P2 (200 ms) were mainly produced in the frontal, temporal, apical, and occipital regions, while the endogenous component P3 (300 ms) was mainly produced in the front-top area, the front-central area, the central-top area, and the top-pillow area. Regarding P1, the information transmission speed was faster than contrasting colours with matching process. Regarding P2, external and internal factors and their interactions significantly affected amplitude, whereas only interactions affected latency, and the interaction was stronger with colour matching. Regarding P3, colour matching type, involved brain area, and interactions had no significant effect on amplitude and latency. The information processing of same colour system in brain has shorter information processing time and faster information transmission. That indicated the EEG technology could provide objective visual cognitive aesthetic rules for silk fabric colour matching, and provide reference value for fabric manufacturers to timely understand consumers' preference for fabric colour categories.
\end{abstract}

Keywords: silk fabric, colour matching, EEG technology, visual cognition, aesthetic law

Un studiu potențial legat de evenimente privind estetica asortării culorilor pe țesătura din mătase

În această lucrare, au fost analizate comportamentul cognitiv și electroencefalografia (EEG) a 16 subiecți care au aplicat asortarea culorilor și contrastul culorilor pe țesăturile din mătase. Rezultatele au arătat că, componentele exogene P1 (100 ms) și P2 (200 ms) au fost produse în principal în regiunile frontale, temporale, apicale și occipitale, în timp ce componenta endogenă P3 (300 ms) a fost produsă în principal în zona frontală superioară, zona centrală frontală, zona centrală-superioară și zona superioară. În ceea ce privește P1, viteza de transmitere a informațiilor a fost mai ridicată decât contrastul culorilor în procesul de asortare. În ceea ce privește P2, factorii externi și interni și interacțiunile acestora au influențat semnificativ amplitudinea, în timp ce doar interacțiunile au influențat latența, iar interacțiunea a fost mai puternică la asortarea culorilor. În ceea ce privește P3, tipul de asortare a culorilor, zona creierului implicată și interacțiunile nu au avut o influență semnificativă asupra amplitudinii și latenței. Procesarea informațiilor din același sistem de culori din creier are un timp de procesare a informațiilor mai scurt și o transmisie mai rapidă a informațiilor. Acest lucru a indicat că tehnologia EEG ar putea oferi reguli estetice cognitive vizuale obiective pentru asortarea culorii țesăturilor din mătase și valoare de referință pentru producătorii de țesături, pentru a înțelege în timp util preferința consumatorilor pentru categoriile de culori.

Cuvinte-cheie: țesătură din mătase, asortarea culorilor, tehnologia EEG, cunoaștere vizuală, lege estetică

\section{INTRODUCTION}

The eyes are considered the windows to the human mind. Upon opening one's eyes, the brain instantly registers visible colours and uses cognition to judge the colour matching which people prefer.

Unsurprisingly, the colour matching of fabrics is an indispensable element of the visual perception of clothing. Accordingly, apparel fabric designers and fabric production companies strive to meet the aesthetic requirements of the public in terms of colour matching. Silk fabric is a primary representative apparel fabric, and the consumer demand for this fabric increases each year. Therefore, a study of visual cognition during the colour matching of silk fabrics could provide a reference for the visual cognition of other fabrics.

Colour matching is a physiological phenomenon produced by the sense of vision, which relies on a balance in the retinal perception of colour. Colour matching can be classified as same colour matching or contrast colour matching, according to the involved hues. Same colour matching refers to the matching of different brightness or purity levels of the same colour [1], such as sky blue and light blue, or rose red and pink. Generally, people find hues within the same colour system to be aesthetically pleasing. Contrast colour matching involves colours that are opposites in the hue circle (i.e., contrast colours). The 
pairing of these colours can yield strong contrasts. This concept also includes contrasts in brightness, warmness/coolness, and area [2], among other properties. Appropriate colour matching can give silk fabrics different artistic styles.

To date, studies of the colour matching of silk fabrics have mainly relied on subjective cognition evaluation methods. Traditional evaluations of subjective cognition are usually based on subjective descriptions and questionnaire surveys. However, these methods cannot accurately record or objectively evaluate the cognition required for colour matching. Currently, evaluations of subjective cognitive are combined mainly with the psychological software E-prime. This universal software package for the development of psychological experiments is equipped with multiple multifunctional expansion packages that can be used with many technical devices at the frontier of psychology research. For example, a new combination of eventrelated potential (ERP), functional magnetic resonance imaging and eye movement, as a software for stimulus presentation and data collection, have being used in the field of textile evaluation $[3,4]$.

In recent years, the development of neurophysiology had led researchers to combine concepts from that field with computer technology for applications in the fields of textiles and clothing. For example, Yoko et al. selected two skirts as stimulating materials in a contrast colour study, which demonstrated that the alpha wave probability of the skirt with higher colour brightness was obviously higher than that of with lower colour brightness [5]. A combination of these data with an evaluation of the sensations of tightness and comfort revealed a change in the $\alpha$ wave intensity that corresponded to the pressure exerted by a belt on the abdomen [6]. Chen et al. had used fourcolour combinations of blue, white, red and yellow, with black as the visual stimuli, determined that N75, P100 and N145 could be used to detect the effects of stimulating materials on human optic nerve production [7-9].

In this study, cognitive behavioural and electroencephalography (EEG) techniques were combined to evaluate cognition during colour matching. Silk fabrics and contrast colour systems were used as stimuli, and ERP signals were collected from the cerebral cortices of 16 female subjects during the process of aesthetic evaluation process [10,11]. The obvious visual components registered by different brain regions were associated with external (colour matching) and internal (brain) factors during three stages: early perception ( $\mathrm{P} 1$ component), combination of physical and biological components (P2 component), and decision (P3 component). The influence of processing in different areas of the brain on amplitude and latency were explored through an analysis of differences in the generated wave frequencies, as well as the distributions and energy distributions of waves of different frequencies in each brain region in response to colour and contrast colour matching.

\section{MATERIALS AND METHODS}

\section{Test subjects}

Sixteen female subjects between 18 and 25 years old were selected, stochastic.

\section{Experimental materials and instruments}

For this experiment, plain satin silk fabric with a weight of $52 \mathrm{~g} / \mathrm{m}^{2}$ was used. The selected materials were scanned to generate a standard image (resolution). The same colour matching analysis included two shades each within the red (rose red and pink) and blue systems (sky blue and light blue). One group: rose red $\times$ pink; sky blue $\times$ light blue; and the other group: red $\times$ blue and red $\times$ green.

The prepared sample was scanned at a resolution of $600 \mathrm{dpi}$ to generate a test image measuring $20 \mathrm{~cm}^{2}$. Each group was matched with nine images for a total of 36. The following equipment was used for the analyses: a computer with E-prime 2.0 (Professional) behavioural software; an EEG amplification and data detection system (Compumedics, Australia); a SynAmp2 amplifier; a 64-lead Quik-Cap electrode cap; Curry 7.0; and Scan4.5 EEG signal acquisition and analysis software.

\section{Experimental paradigm and experimental process}

Prior to the experiment, the subject was informed about the experiment and precautionary measures. The subject was required to pay attention to the contents of the visual presentation and react quickly [10]. No influencing visual stimuli were provided in the idle state. Therefore, the combination of the same colour system and contrast colour system was the main component of the ERP analysis.

At the beginning of the experiment, the subjects were exposed to visual stimuli intended to elicit brain waves. The experimental paradigm is shown in figure 1. In each experiment, E-prime 2.0 software was used to display the same colour matching and contrast colour matching images on the screen in a random order [11]. The subjects were required to assign aesthetic scores rapidly (presentation time: $500 \mathrm{~ms}$ ) to ensure that the evaluation was completed. Each subject was instructed to press the $Z$ button with their left hand if they deemed the presented image to be US, and to press the $\mathrm{M}$ button with their right hand if the image was not aesthetically pleasing.

Each image evaluation was followed by an idle period of $100 \mathrm{~ms}$ to prevent the visual impact of the previous image. A red "+" flashed on the screen to indicate that the next presentation time would occur in $50 \mathrm{~ms}$, thus prompting the subject attention [12-14].

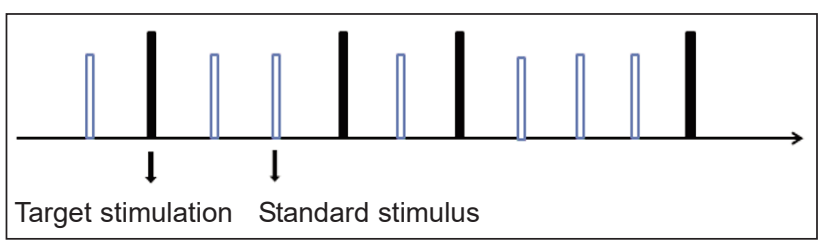

Fig. 1. Paradigm of random image presentation 


\section{Data collection}

During the experiments, the sampling frequency and mode were $1000 \mathrm{~Hz}$ and DC, respectively, and the ears were used as the reference electrode sites. The electrode distribution is shown in figure 2. Raw data were pre-processed using the Curry 7.0 EEG analysis software, which performed artefact removal and correction, EEG segmentation, and baseline correction. The start time of each stimulus was set as zero, and the stimulus was selected according to the time interval set by the experimental paradigm. $800 \mathrm{~ms}$ after the start as the analysis data, this is suitable for the $100-200 \mathrm{~ms}$ and $200-300 \mathrm{~ms}$ and 300-600 ms latency of the exogenous and endogenous components. The time for baseline correction is usually equal to $1 / 10-1 / 5$ length of the whole analysis [15]. Therefore, a point of $200 \mathrm{~ms}$ before the start of the stimulation was selected for the superimposed average baseline correction data.

\section{Analysis of exogenous component data}

The data were compared using a two-factor repeated measures analysis of variance and mean analysis. If the results of the analysis of variance (ANOVA) violated the spherical hypothesis (i.e., Mauchly spherical test, $\mathrm{P}<0.05)$, then the Huynh-Feldt degrees of freedom were used for correction [16].

\section{RESULTS AND DISCUSSIONS}

The ERP waveform and topographic image analysed revealed that the P1 and P2 components were produced in the frontal and temporal regions, while significant P3 components were produced in the top and occipital and temporal regions. $\mathrm{P} 1$ and $\mathrm{P} 2$ were corresponding to exogenous components. P1 was generated during the sensing stage, while $\mathrm{P} 2$ was generated from a combination of physical and biological components, and P3 components were endogenous and be generated during the decision-making stage. The frontal, temporal, apical, and occipital regions were mainly include the component of F3, F4, T7, T8, P3, P4, O1, O2, CP1, CPz, CP2, PO3, POz and PO4, from which could lead to difference of the waveform very significantly with the baseline. In this case, the typical electrode points F3, F4, T7, T8, P3, P4, O1 and $\mathrm{O} 2$ in these areas were selected for the EEG waveform analysis. Among these, blue colour worked as the same colour waveform, and red colour as the contrast colour waveform.

P1 was mainly observed in the bilateral occipital region and generally initiated at $60-90 \mathrm{~ms}$ after the start of stimulation, with a peak between 100 and 130 $\mathrm{ms}[17,18] . \mathrm{P} 2$, which observed in the central region of the forehead, was a significant positive component with an incubation period of approximately $200 \mathrm{~ms}$ and it could lead to the strongest visual stimulation response in the back of the scalp. The enlarged ERP brain waveform with electrode point was shown in figure 3 according to the magnitude of the amplitude. According to the waveform diagram, the P1 and P2

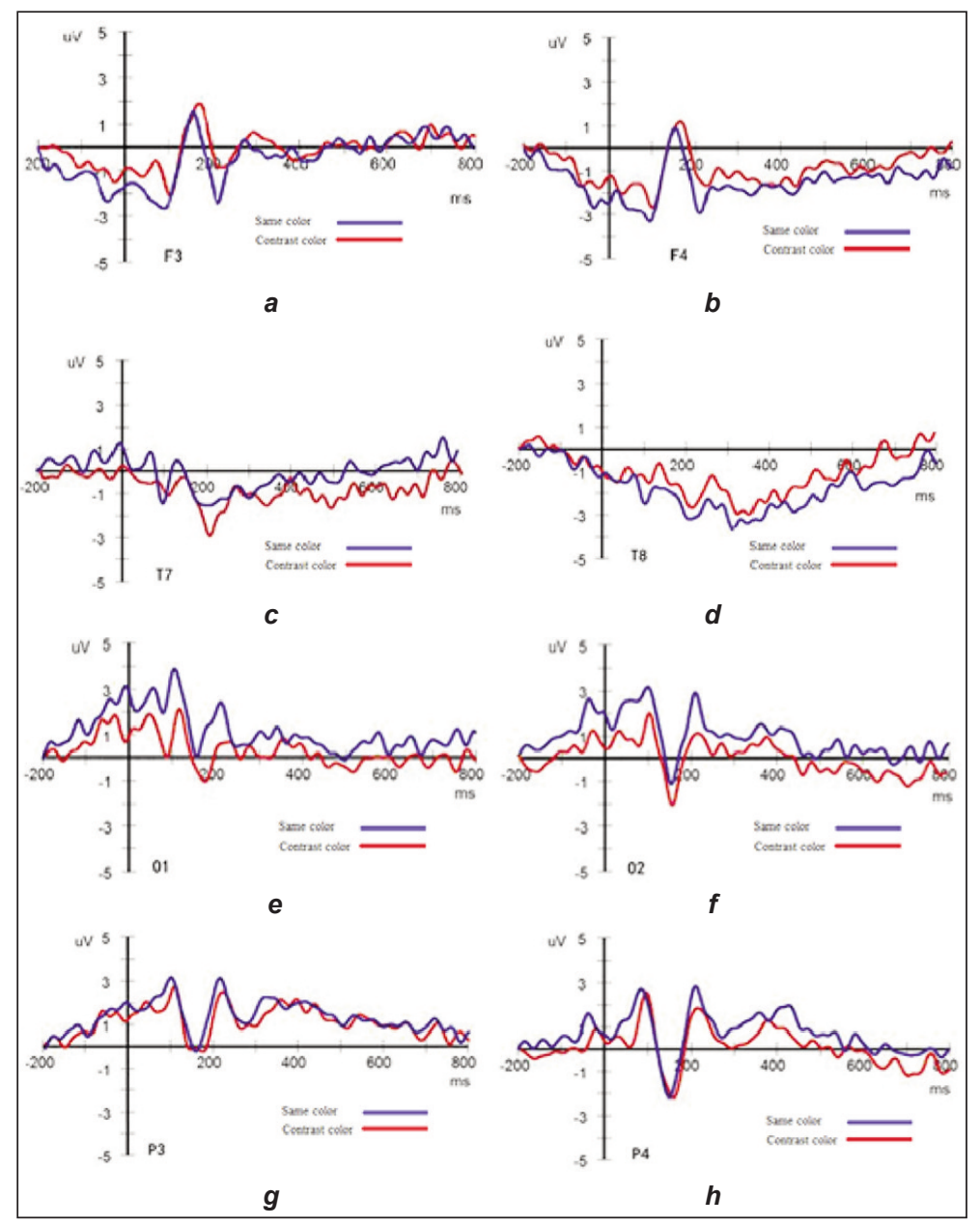

Fig. 3. The images of EEG waveforms: $a$ - electrode point F3; $b$ - electrode point F4; $c$ - electrode point T7; $d$ - electrode point T8; $e$ - electrode point $\mathrm{O} 1 ; f$ - electrode point $\mathrm{O} 2 ; g$ - electrode point $\mathrm{P} 3$; $h$ - electrode point $\mathrm{P} 4$ 


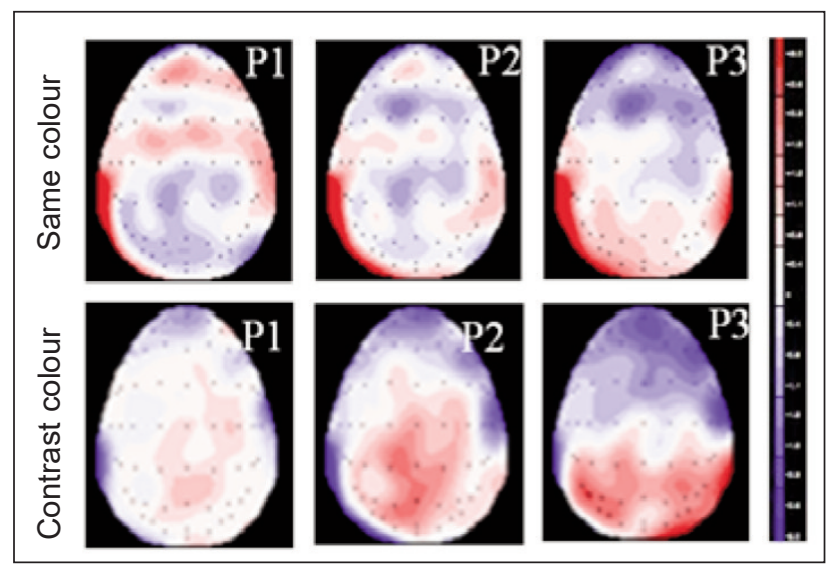

Fig. 4. Brain topographic images of the three components

components induced by the contrast colour matching were larger than the contrast colour matching, and the top region and the pillow were in the top region. The district is the opposite. P3 had a relatively large amplitude and wide span and induced by rare, taskrelated stimuli (i.e. target stimuli). Generally, the incubation period of P3 was approximately at $300 \mathrm{~ms}$ [19-21], and usually distributed in the central-top region near the midline. The P3 component was selected according to the magnitude of the amplitude. An example ERP brainwave waveform was shown in figure 4, which indicated that the amplitude of the EEG was greater than the contrast colour, while the amplitude of the contrast colour in the frontal region was greater than the same colour. The amplitude of the contrasting colour in the central top region and the occipital region was larger than the contrast colour

The EEG signal was input into Scan 4.5 software and converted into an EEG topographic image. The P1 component induced by the same colour system was more prominent in the temporal and frontal regions, while the P2 component amplitude was greater than the P1 component amplitude. The component P3 was mainly distributed in the top and occipital zones, where the amplitude was larger. The induction of the P1 component by the contrast colour system yielded small and insignificant amplitude. The P2 component was mainly distributed in the top and occipital zones. The P3 component was mainly distributed in the top and occipital zones, and the amplitude was significantly greater than the amplitude of the exogenous component.

\section{Analysis of P1 component data}

The main effects and interactions of external factors (colour matching) and internal factors (brain processing) on the amplitude and latency of each component were explored experimentally. Two external factors levels, colour matching and contrast colour matching were used, while four internal factor levels, frontal area processing, squatting area processing, top area processing, and occipital area processing were used. The results of amplitude and latency variance analyses were shown in tables 1 and 2 . The difference in amplitude was not significant, and the main effect of

\begin{tabular}{|l|c|c|c|c|c|}
\hline \multicolumn{7}{|c|}{ RESULTS OF A P1 AMPLITUDE VARIANCE ANALYSIS } \\
\hline \multicolumn{1}{|c|}{ Source } & Type III square sum & df & Mean square & F & Sig. \\
\hline Colour matching & 6.065 & 1.000 & 6.065 & 0.540 & 0.474 \\
\hline Error (colour matching) & 168.579 & 15.000 & 11.239 & - & - \\
\hline Brain processing & 1359.695 & 1.494 & 910.268 & 140.817 & 0.000 \\
\hline Error (brain processing) & 144.836 & 22.406 & 6.464 & - & - \\
\hline $\begin{array}{l}\text { Colour matching *Brain } \\
\text { processing }\end{array}$ & 22.549 & 1.856 & 12.147 & 4.764 & 0.019 \\
\hline $\begin{array}{l}\text { Brain processing (Colour matching } \\
\text { *Brain processing) }\end{array}$ & 70.996 & 27.845 & 2.550 & - & - \\
\hline
\end{tabular}

\begin{tabular}{|l|c|c|c|c|c|}
\hline \multicolumn{7}{|c|}{ P1 LATENCY ANALYSIS OF VARIANCE } \\
\hline \multicolumn{1}{|c|}{ Source } & Type III square sum & df & Mean square & \multicolumn{1}{c|}{ F } & Sig. \\
\hline Colour matching & 10090.877 & 1.000 & 10090.877 & 51.502 & 0.000 \\
\hline Error (colour matching) & 2938.967 & 15.000 & 195.931 & - & - \\
\hline Brain processing & 13108.193 & 1.812 & 7235.708 & 8.737 & 0.002 \\
\hline Error (brain processing) & 22504.963 & 27.174 & 828.181 & - & - \\
\hline $\begin{array}{l}\text { Colour matching *Brain } \\
\text { processing }\end{array}$ & 21278.506 & 2.975 & 7153.407 & 24.841 & 0.000 \\
\hline $\begin{array}{l}\text { Brain processing (Colour matching } \\
\text { *Brain processing) }\end{array}$ & 12848.775 & 44.619 & 287.967 & & - \\
\hline
\end{tabular}




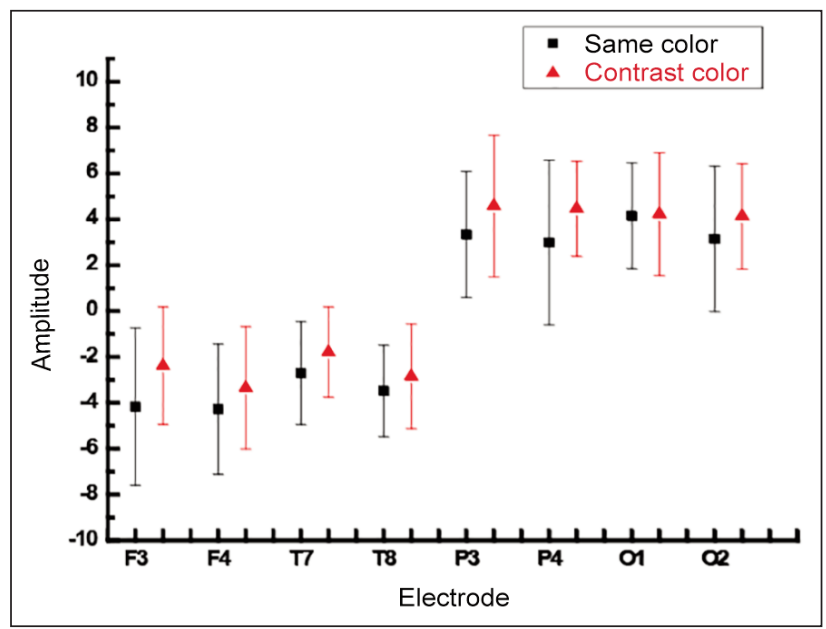

a

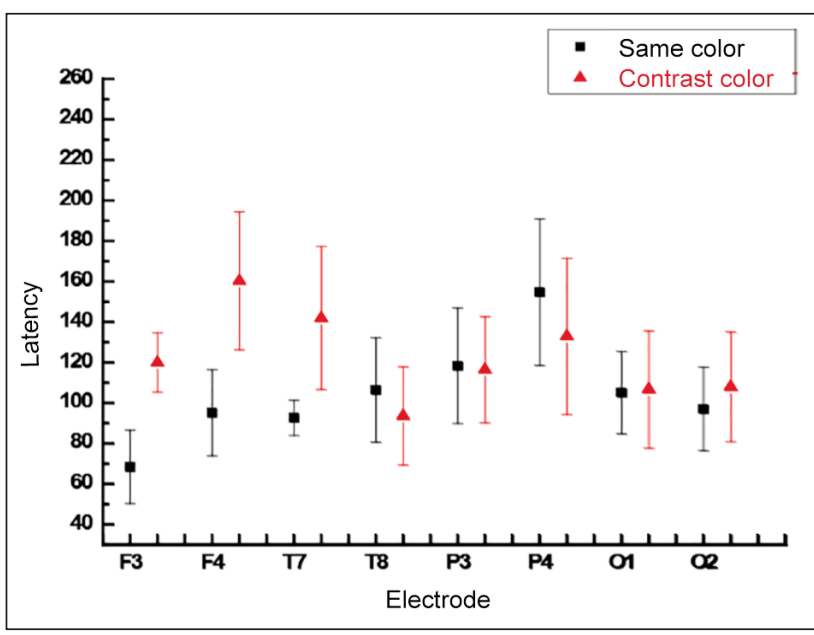

b

Fig. 5. Graphical representations of:

$a$ - Mean component amplitude images of $\mathrm{P} 1 ; b$-Average component latency of $\mathrm{P} 1$

the main effect on the amplitude was significantly differently, while the interaction was also significant. The external and internal factors had significant main effects on early component latency, and the interaction between the two types of factors was also significant.

According to a comparison analysis of the mean value, the same colour and contrast colour were combined to produce negative waves in the frontal and temporal regions, although the same colour system produced higher amplitude than the contrast colour system. Positive waves were produced in the top and occipital regions, and the contrast colour system induced higher amplitude. The amplitude changes induced by the same colour system and contrast colour were consistent in the process from the frontal area to the occipital area, and both are excessively positive waves from negative waves. In the frontal, temporal, and occipital areas, contrast colour matching induced greater latency than same colour matching, indicating that the latter information was transmitted more rapidly in the brain, and the top area information transmission speed is opposite, while the same colour line matches from the frontal area to the occipital area. The results indicating that the speed of information transmission was initially decreased and then increased, the speed of informa- tion transmission from the contrast colour matching area to the temporal area changed rapidly, and the top area and the pillow area are smaller.

\section{Analysis of P2 component data}

The main effects and interactions of the external and internal factors on the amplitude and latency of each component were explored. The results of amplitude and latency analyses and the main effects of external causes are shown in tables 3 and 4 . The difference in amplitude was not significant, and the main effect of the amplitude and the interaction was significant different. Although the main effects of individual external and internal factors were not significant, but the interaction between the two types of factors was significant, indicating that the aesthetic values of different colour collocations during the late processing stage were the result of a combination of brain processing and colour matching. However, the impact of the incubation period duration was not significant. According to the mean value chart, when two colours were matched, the amplitudes in the frontal and sputum area were negative and changed only slightly, whereas the amplitudes of the top and occipital areas were positive and changed only slightly. The amplitudes were greater in response to same colour matching than to contrast colour matching. When the

\begin{tabular}{|l|c|c|c|c|c|}
\hline \multicolumn{7}{|c|}{ RESULTS OF P2 COMPONENT AMPLITUDE VARIANCE ANALYSIS } \\
\hline \multicolumn{1}{|c|}{ Source } & Type III square sum & df & Mean square & F & Sig. \\
\hline Colour matching & 0.129 & 1.000 & 0.129 & 0.006 & 0.938 \\
\hline Error (colour matching) & 310.021 & 15.000 & 20.668 & - & - \\
\hline Brain processing & 595.736 & 1.175 & 507.056 & 21.738 & 0.000 \\
\hline Error (brain processing) & 411.083 & 17.623 & 23.326 & - & - \\
\hline $\begin{array}{l}\text { Colour matching *Brain } \\
\text { processing }\end{array}$ & 292.817 & 1.536 & 190.676 & 16.589 & 0.000 \\
\hline $\begin{array}{l}\text { Brain processing (Colour matching } \\
\text { *Brain processing) }\end{array}$ & 264.774 & 23.035 & 11.494 & - & - \\
\hline
\end{tabular}




\begin{tabular}{|l|c|c|c|c|c|}
\hline \multicolumn{7}{|c|}{ P2 COMPONENT LATENCY ANALYSIS OF VARIANCE } \\
\hline \multicolumn{1}{|c|}{ Source } & Type III square sum & df & Mean square & F & Sig. \\
\hline Colour matching & 89.445 & 1.000 & 89.445 & 0.178 & 0.679 \\
\hline Error (colour matching) & 7541.992 & 15.000 & 502.799 & - & - \\
\hline Brain processing & 374.484 & 1.909 & 196.209 & 0.734 & 0.483 \\
\hline Error (brain processing) & 7655.828 & 28.629 & 267.415 & - & - \\
\hline $\begin{array}{l}\text { Colour matching *Brain } \\
\text { processing }\end{array}$ & 74350.352 & 1.529 & 48637.705 & 192.428 & 0.000 \\
\hline $\begin{array}{l}\text { Brain processing (Colour matching } \\
\text { *Brain processing) }\end{array}$ & 5795.711 & 22.930 & 252.758 & - & - \\
\hline
\end{tabular}

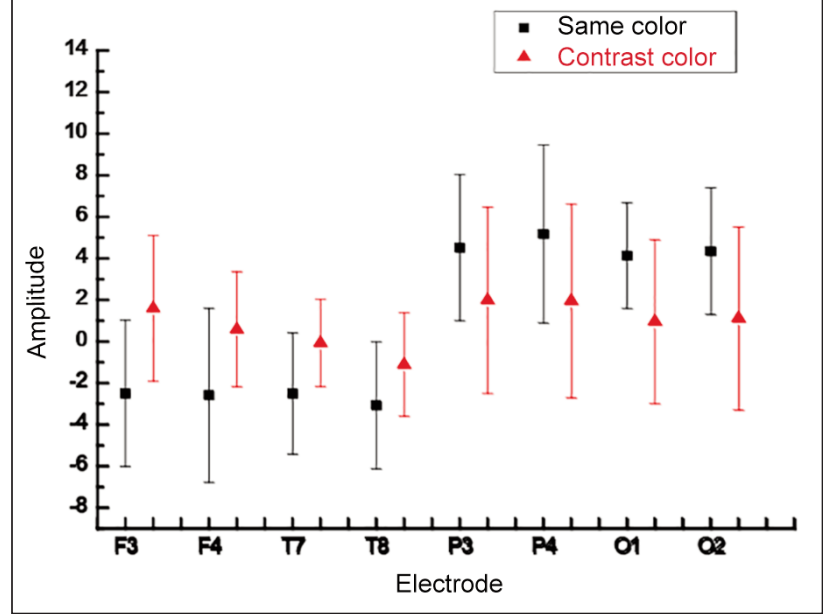

a

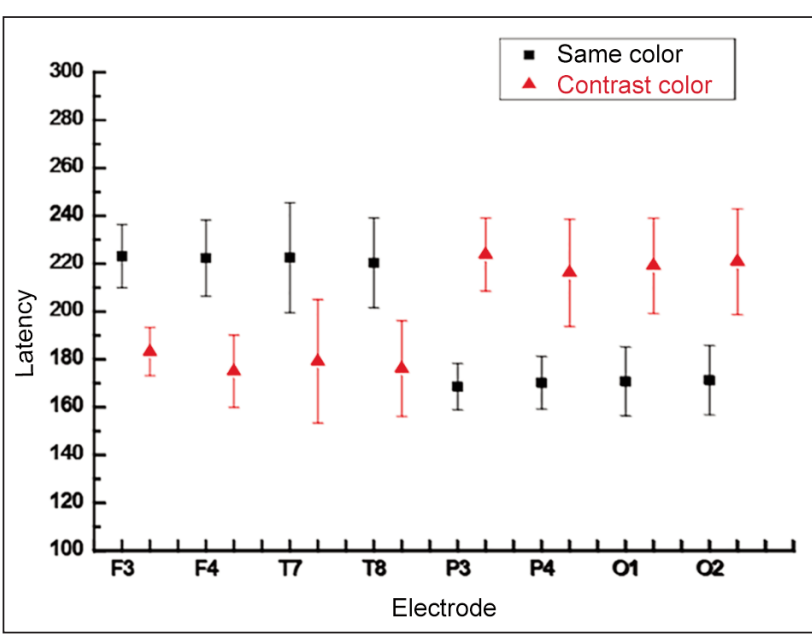

b

Fig. 6. Graphical representations of:

$a$ - Mean component amplitude images of P2; $b$-Average component latency of P2

amplitude of the top and bottom areas in the area began to change, more rapid matching periods were observed in the frontal and temporal areas during same colour matching relative to contrast colour matching. That indicating the transmission speed of contrast colour information was more rapid and that opposite patterns were observed in the top and occipital areas.

\section{Analysis of P3 endogenous component data}

The main effects and interactions of external and internal factors on the amplitude and latency were explored. Two external factor levels (same colour matching and contrast colour matching) and three internal factors (frontal area, top zone, and occipital zone processing) were included. The results of amplitude and latency variance analyses were shown in tables 5 and 6 . The main effects of internal and external factors, and the interactions between the both did not have significant effects on either amplitudes or latencies of the P3 components. In other words, during the decision-making making stage, the speeds of colour information transmission did not differ significantly within different brain regions, and the information

\begin{tabular}{|l|c|c|c|c|c|}
\hline \multicolumn{7}{|c|}{ RESULTS OF P3 COMPONENT AMPLITUDE VARIANCE ANALYSIS } \\
\hline \multicolumn{1}{|c|}{ Source } & Type III square sum & df & Mean square & F & Sig. \\
\hline Colour matching & 1.000 & 5.875 & 0.307 & 0.588 & \\
\hline Error (colour matching) & 287.059 & 15.000 & 19.137 & - & - \\
\hline Brain processing & 34.465 & 2.000 & 17.233 & 2.727 & 0.082 \\
\hline Error (brain processing) & 189.566 & 30.000 & 6.319 & - & - \\
\hline $\begin{array}{l}\text { Colour matching *Brain } \\
\text { processing }\end{array}$ & 1.472 & 1.359 & 1.083 & 0.162 & 0.767 \\
\hline $\begin{array}{l}\text { Brain processing (Colour matching } \\
\text { *Brain processing) }\end{array}$ & 136.061 & 20.390 & 6.673 & - & - \\
\hline
\end{tabular}




\begin{tabular}{|l|c|c|c|c|c|}
\hline \multicolumn{7}{|c|}{ P3 COMPONENT LATENCY ANALYSIS OF VARIANCE } \\
\hline \multicolumn{1}{|c|}{ Source } & Type III square sum & df & Mean square & F & Sig. \\
\hline Colour matching & 166.251 & 1 & 166.251 & 0.239 & 0.632 \\
\hline Error (colour matching) & 10439.841 & 15 & 695.989 & - & - \\
\hline Brain processing & 5192.583 & 1.206 & 4307.095 & 3.692 & 0.064 \\
\hline Error (brain processing) & 21096.972 & 18.084 & 1166.621 & - & - \\
\hline $\begin{array}{l}\text { Colour matching *Brain } \\
\text { processing }\end{array}$ & 16.287 & 1.26 & 12.925 & 0.029 & 0.912 \\
\hline $\begin{array}{l}\text { Brain processing (Colour matching } \\
\text { *Brain processing) }\end{array}$ & 8358.898 & 18.902 & 442.233 & - & - \\
\hline
\end{tabular}
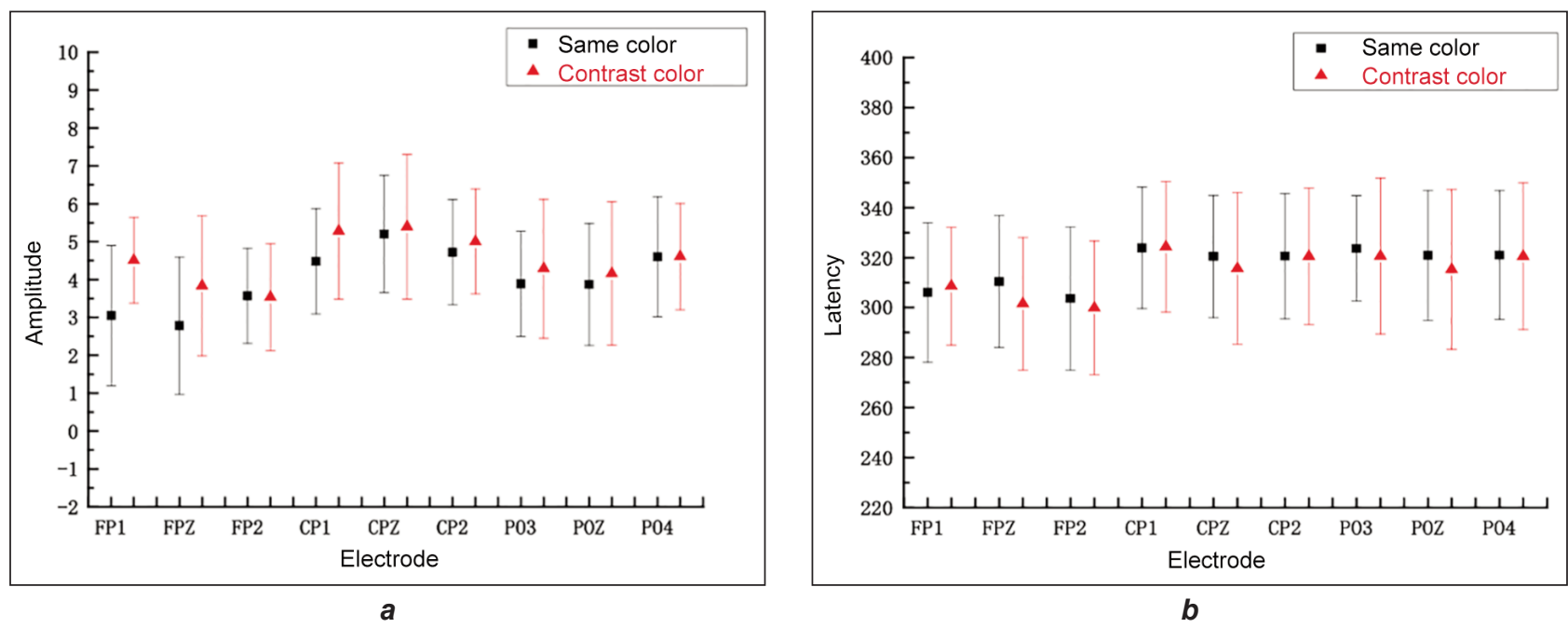

Fig. 7. Graphical representations of:

$a$ - Mean component amplitude images of P3; $b$-Average component latency of P3

transmission speeds among different brain regions were highly similar.

The mean amplitude values suggest that in the decision-making stage, the contrast colour system induced greater than the same colour system in different brain regions. The average value of the amplitudes induced in different brain regions was positive, with the highest amplitude induced in the central-top region followed by the top-pillow area and frontal area. The same colour system induced a higher latency value than the contrast colour system, indicating that the former required a shorter information processing duration and yielded more rapid information transmission in different brain regions. Greater latency was observed in the central-top region and top-pillow region relative to the frontal region, indicating that information processing occurred mainly in the top and pillow areas.

\section{CONCLUSIONS}

In this paper, same colour and contrast colour matching tasks were explored by 16 subjects between 18 to 25 years old. The aesthetic evaluation involved both exogenous and endogenous components, each of which affected by different brain regions. The influence of internal and external factors on amplitude and incubation period of each component was different.
For P1 component, the information transmission speed of homochromatic system collocation in brain area was faster than that of contrast system collocation. For P2 component, the information transmission speed of the contrast colour system was faster, and the same colour system was slower. For P3 component, the information processing time of the same colour system collocation in different brain regions was shorter, and the information transfer speed was fast. When the subjects evaluated the colour matching of silk fabrics, the top and occipital areas were more sensitive to the matching of the same colour system. The amplitude of P1 and P2 components was larger than that of the matching of the contrast colour system. The frontal and temporal areas were more sensitive to the matching of the contrast colour system. The amplitude of P1 and P2 components was larger than that of the matching of the same colour system. To summarize, the results indicated that, the EEG technology could provide objective visual cognitive aesthetic rules for silk fabric colour matching, and provide reference value for fabric manufacturers to timely understand consumers' preference for fabric colour categories.

\section{ACKNOWLEDGEMENTS}

This research was funded by Zhejiang Provincial Natural Science Foundation of China (No. LQ18E030009). 


\section{REFERENCES}

[1] Andreas, H., Rukun, H., Keliris, G.A., Philipp, B.-S., On the usage of brain atlases in neuroimaging research, In: Molecular Imaging and Biology, 2018, 20, 5, 742-749

[2] Hong, Y., Zeng, X., Bruniaux, P., Liu, K., Chen Y., Framework of Consumer Perceived Value On Fashion Products For Female College Students In France, In: Industria Textila, 2018, 69, 6, 495-501, http://doi.org/10.35530/ IT.069.06.1408

[3] Chen, Y., Yang, L., Clinical analysis of EEG, EEG topography, CT and MRI in diagnosis of central nervous system infection, In: Chinese and Foreign Medical, 2018, 37, 2, 184-185, 188

[4] Coricelli, C., Toepel, U., Notter, M.-L., Murray, M.M., Rumiati, R.I., Distinct brain representations of processed and unprocessed foods, In: European Journal of Neuroscience, 2019, 50, 8, 3389-3401

[5] Guo, Y., Wei, Z., Hu, Q., Li, S., Wang, W., Zhang, L., Lu, J., Zhang, J., Yan, J., Chen, Y., Wei, Y., Analysis of "Heart" effect of different sexual college students induced by baduanjin based on $\beta$-band EEG power spectrum, In: Journal of Beijing University of Traditional Chinese Medicine, 2017, 40, 8, 653-660

[6] Ji, X., Diagnosis and analysis of EEG, EEG topography, CT and MRI of central nervous system infection, In: Capital Food and Medicine, 2018, 25, 16, 80

[7] Kabir, S.M.M., Dhar, A.K., Bhattacharjee, M., The use of natural Areca catechu dyes for silk and nylon and its halochromic effect, In: Journal of the Textile Institute, 2019, 1674542

[8] Li, M., Zhang, L., An, Y., Ma, W., Fu, S., Relationship between silk fabric pretreatment, droplet spreading, and inkjet printing accuracy of reactive dye inks, In: Journal of Applied Polymer Science, 2018, 135, 46073

[9] Li, N., Liu, M., Niu, L., Study on the effect of fatigue on miner migration by event-related potentials, In: Chinese Journal of Safety Science, 2019, 29, 2, 1-6

[10] Li, Y., Zhang, L., Zhang, T., Li, B., A study of the application of Brain Atlas with and without plus Gz acceleration conditions, In: Technology and Health Care, 2017, 25, 443-S448

[11] Liu, C., Wang, J., Deng, B., Li, H., Fietkiewicz, C., Loparo, K.A., Noise-Induced improvement of the parkinsonian sate: a computational study, In: IEEE Transactions on Cybernetics, 2019, 49, 10, 3655-3664

[12] Lo Giudice, P., Mammone, N., Morabito, F.C., Pizzimenti, R.G., Ursino, D., Virgili, L., Leveraging network analysis to support experts in their analyses of subjects with $M C l$ and $A D$, In: Medical \& Biological Engineering \& Computing, 2019, 57, 9, 1961-1983

[13] Lu, Y., Ren, Q., Zong, L., Wu, Y., Zhang, Q., Ma, X., Pu, Q., Dong, H., Preliminary study on EEG nonlinear dynamics in patients with insomnia, In: International Journal of Psychiatry, 2014, 41, 3, 129-132

[14] Ma, M., Hussain, M., Dong, S., Zhou, W., Characterization of the pigment in naturally yellow-coloured domestic silk, In: Dyes and Pigments, 2016, 124, 6-11

[15] Qian, W., Liu, G., Zhou, Q., Effects of changes in EEG topography on depression and cognitive function in patients with depression, In: Chinese Journal of Health Psychology, 2017, 25, 10, 1441-1444

[16] Ellison S.L.R., Barwick, V.J., Farrant, T.J.D., Analysis of Variance, In: Practical Statistics for Analytical Scientist: A Bench Guide: Edition 2, 2009, Chapter 6, 59-91

[17] Ye, P., Wu, X., Gao, D., Liang, H., Wang, J., Deng, S., Xu, N., She, J., Chen, J., Comparison of DP3 signals evoked by comfortable 3D images and 2D Images - an event-Related potential study using an Oddball Task, In: Scientific Reports, 2017, 7, 43110

[18] Yue, J., Zhang, X., Wang, G., Research on the application of cognitive behaviorology to silky tactile evaluation, In: Silk, 2014, 51, 9, 23-27

[19] Zhang, A., Study on the application of EEG topographic maps in the diagnosis of brain tumors, In: World Journal of Integrated Traditional Chinese and Western Medicine, 2012, 7, 5, 441-442

[20] Zhang, H., Jia, J., Wang, G., Evaluation of silk fabric colour based on cognitive behavior, In: Modern Silk Science and Technology, 2018, 33, 5, 13-16

[21] Zhang, N., Zhou, Z., Liu, Y., Yin, E., Jiang, J., Hu, D., A novel single-character visual BCl paradigm with multiple active cognitive tasks, In: IEEE Transactions on Biomedical Engineering, 2019, 66, 11, 3119-3128

\section{Authors: \\ KAIWEI NIE ${ }^{1,2}$, RUN WEN ${ }^{3}$, HUANPING MO $^{1}$, XIAOXIA ZHANG $^{4}$, ZHONG WANG $^{1}$, GUOHE WANG $^{1}$}

${ }^{1}$ College of Textile and Clothing Engineering, Soochow University, Suzhou 215006, China

${ }^{2}$ Suzhou Tianshe Silk Co., LTD, 215001, China

${ }^{3}$ College of Textiles, Donghua University, Shanghai 201620, China

${ }^{4}$ School of Fashion, Zhejiang Sci-Tech University, Hangzhou, Zhejiang 310018, China

\section{Corresponding authors:}

ZHONG WANG

e-mail: wangzhong1215@suda.edu.cn

GUOHE WANG

e-mail: wangguohe@suda.edu.cn 